\title{
Evaluation of the Determinants of Technological and Managerial Results of Cooperability in Brazilian Multinationals
}

\author{
Priscila Rezende da Costa', Geciane Silveria Porto², Antonio Thiago Benedete da Silva ${ }^{3}$
}

\begin{abstract}
The objective of this article was to evaluate the technological and managerial elements that determine the results of the cooperability in Brazilian multinationals (BMN).We conducted a survey among the universe of BMN and the data analysis was supported by Cronbach's Alpha testing, factorial analysis, correlation analysis, principal component analysis and multiple regression analysis. As a conclusion of the study on the elements of the technological trajectory, we found that the greater the experience in R\&D in the headquarters, the more effective will be the technological results of cooperability and the greater the accumulated experience in R\&D in foreign subsidiaries and international cooperation the more effective will be the managerial results of cooperability. We also found that the greater the degree of relevance of strategies for technological capacity building the more effective will be the results of cooperability, both technological and managerial. The aggregated analysis of technological inputs showed that the higher the investments in R\&D and the number of internal and cooperative projects the more effective will be the technological results. However, as the company expands its project portfolio, grow the difficulties regarding alignment and management of the BMN, which may adversely affect the managerial results of cooperability.
\end{abstract}

Keywords: innovation; cooperation; trajectory; technological inputs; brazilian multinationals.

\footnotetext{
'UNINOVE, Avenida Dr. Adolpho Pinto, 109, Barra Funda; São Paulo - SP, Brasil. E-mail: priscilarc@uninove.br ${ }^{2}$ FEA-RP/USP, Estrada dos Bandeirantes, 3900, Monte Alegre; Ribeirão Preto - SP, Brasil. E-mail: geciane@usp.br ${ }^{3}$ UNINOVE, Avenida Dr. Adolpho Pinto, 109, Barra Funda; São Paulo - SP, Brasil. E-mail: atbenedete@usp.br
} 


\section{Introduction}

Markets are becoming more dynamic nowadays, and new forms of competition arise demanding that companies seek to adapt and explore changes in their business environments, and look for opportunities to create new technological and strategic cycles (Teece, 1997). To survive and prosper under conditions of change, firms must develop "dynamic capabilities" to create, extend and modify the ways in which survive (Helfat et al., 2007).

To develop "dynamic capabilities", mainly those related to innovation, it is necessary to understand its dispersion (Andrade, 2010). This implies that a company alone does not have all the capabilities it needs, instead, they are increasingly spread across internal and external contexts. These capabilities, in turn, are not developed in isolation, often depending on interactive innovative processes or simple exchanges (Chesbrough et al., 2008).

The dynamic ability to innovate and manage its attributes of dispersion and interactions are essential factors to survival and success of a company in the 21 st century. In the past, it was a necessity for only a select group of large incumbents from developed countries. Today is also a priority for many emerging companies from developing countries (Hitt, 2008). It is worth noting that in the context of growth and competitiveness of emerging companies, the current challenge does not depend solely on the local generation of products and processes innovations, but involves the dynamic capability of generating innovative solutions and new business models also on a global scale, emerging, then, the competitive challenge of internationalization (Doz et al., 200I).

Santos (2006) points out that the future success of emerging multinationals, specifically the Brazilian, depends on the ability to access knowledge outside of its subsidiaries and headquarters and join it to the capacities of their global operations and technological cooperation networks (Almeida, 2007). This construction will require intense improvement in the ability to organize knowledge that is dispersed into its vast network of technological partners and subsidiaries (Cyrino and Barcellos, 2006).

As they mobilize and share knowledge globally dispersed, emerging multinationals can innovate more effectively and with better results than rivals that remain attached to their nationality (Leydesdorff and Etzkowitz, 200I). It is exactly at this point where the value of a company is determined by the creation, expansion and modification of the ways it remains innovative and competitive in the global market place, and that cooperation with external sources plays an important role, because it brings the possibility to integrate the suppliers and demanders of innovation and these can dynamically generate ways to share knowledge and skills and generate innovations often difficult and / or impractical to be generated individually (Leydesdorff and Meyer, 2006).

Despite the potential benefits, cooperation activities require effort and dedication of the actors involved (Simard and West, 2008), and strategic, managerial and structural procedures changes which must be developed and commonly accepted, implemented and made flexible by partners, resulting on the development of skills and competencies not only technological, but for the management of tangible and intangible resources (Carayannis and Campbell, 2009).

Given these challenges, there is a growing academic and business interest regarding the characteristics of organizations that have created a differentiated ability to cooperate, which included more complex and challenging relations, because they result in the expansion of the resource base of partners and creation of specific values that emerge from the assets and resources involved in cooperative relationships (Hanel and Pierre, 2006). Companies that are able to systematically achieve gains from cooperation typically adopt formal management techniques to run it, use a deliberated managerial process and structure cooperation decisions (Berghe and Guild, 2008).

At this point, it is necessary to articulate the concept of cooperability in the context of emerging multinationals, whose definition can be summarized as follows: cooperability is the ability to dynamically develop intentional cooperative projects, where partners create and / or share technological and innovation resources in local and / or global contexts.

The adoption of the concept of cooperability will turn the challenges of emerging multinationals more complex, as these companies will develop and systematize strategies, structures and administrative practices for search, selection, implementation and management of local and global cooperative relations. The concept of cooperability requires that cooperative relations, particularly those focused on innovation and technology, can be developed with various external partners, which will require of these multinationals the development of organizational skills to handle and manage the relationship with different innovation sources.

Despite the relevance of cooperability to business competitiveness of emerging multinationals and for strengthening the national innovation systems of developing economies, it is a fact that the pure concept of cooperation with external sources of technology is not new and its barriers and facilitators are already documented in the academic literature. However, what is new is the analysis of which are the trajectory (path) and inputs (business drivers) of cooperation and the influence of these elements on the results of cooperabil- 
ity. Given that, we present the following research question: What technological and managerial elements determine the results of cooperability in Brazilian multinationals?

We aim, specifically, to: (a) analyze the profile of the BMN, (b) assess whether the elements of the technological trajectory interfere in the results of cooperability and (c) assess whether technological inputs affect the results of cooperability. It is worth noting that the study object of the research is related to Brazilian multinationals (headquarters as a locus for research), here defined as companies (I) whose capital is national (greater than or equal to $50 \%$ of voting capital), (2) with production units or business abroad, (3) that maintain international R\&D units or have cooperative projects with foreign STI (Scientific and Technological Institutions).

\section{Theoretical Framework}

\section{Dynamic Capabilities and Open Innovation}

Dynamic capabilities refer to the ability of the firm to integrate, build and reconfigure internal and external competencies. In this definition, organizational skills denote managerial and organizational processes or current models of practice and learning. Changing the resource base of the organization, dynamic capabilities can then open new strategic alternatives or "paths" for the firm (Eisenhardt and Martin, 2000).

According to Teece et al. (2007) the development and deployment of dynamic capabilities (not imitable) by a firm will determine the nature and amount of resources that give rise to the profit it will get. It indicates that the past will impact the present and future performance, ie companies suffer "path dependency." The management of an organization can design processes and structures to support innovation and, at the same time, the company can get rid of dysfunctional processes and structures, thus breaking this dependency path.

Note that dynamic capability includes the ability to identify the need or opportunity to change, to create an answer to this need or opportunity, and to implement a course of action. Not all dynamic capabilities are related to these three functions. In fact, the dynamic capabilities serve different purposes, they are always related to changes and allow businesses to enter new businesses or expand existing businesses through internal growth, acquisitions and strategic partnerships, while others help the company to create new products and production processes and promote profitable growth (Helfat et al, 2007).

To understand how organizations identify and respond to changes, it is necessary to examine the adjacent managerial and organizational processes. The transformation of an organization, through actions, cancellations or changes in its resource base, implies processes to achieve change and therefore it is necessary to understand which and how organizations develop their resource base (Winter, 2003). In this context, Helfat et al (2007) define "dynamic capacity" as the ability of an organization to create, extend or modify purposely its resource base. A "resource base" includes an organization's tangible, intangible and human assets (or resources), as well as the capabilities that the organization owns, controls or has access through partnerships.

The dynamic capabilities approach is especially relevant for innovation and cooperation, as more important than the current resource base is the ability to internally and externally accumulate and combine new resources, especially if these interactions contribute to building distinctive competencies in areas such as R\&D, new products and processes, new business models, among others.

In this context, it is evident the importance of combining internal and external ideas into architectures and systems shaped by business models that create and capture value. The important role assumed by the business models enables organizations to sustain valuable position in the industry over time. Moreover, the race for competitive advantage also goes by external applications for technologies internally developed and unused, either through new business models and licensing to third parties (Chesbrough et al., 2008).

The novelty introduced by Chesbrough et al (2008) is the proposition of reshape the business model of the company, based on the systematization of interactions with external actors in the innovation process. Such systematization should be incorporated into the corporate strategy of the company in the form of specific internal processes, mobilization of human and financial resources, adaptation of skills and internal culture to the new model. Thus, the implementation of open innovation translates into a systematic set of organizational initiatives in R\&D that the company can adopt jointly to accelerate its pace of innovation generation (Van Der Meer, 2007).

Chiaroni et al (2010) argue that the adoption of a strategy of open innovation demands new systematic actions and new skills in collaborative activities, via processes and routines within the company. Ferro (2010) also emphasizes that the success of an open innovation strategy is based on developing certain skills and resources. This development process involves the identification of the main sources of innovation for the company, able to bring sustainable competitive advantages. Then the company must devote to understanding the peculiarities and dynamics of the operation of the activities developed by these sources, and from this analysis, outlining selection criteria of these different sources and outline 
guidelines for their attraction and for the establishment and running of partnerships with each type of source. In addition, efforts are needed in defining processes and evaluation and internalization of learning arising from these partnerships metrics. From this point, it is possible to say that the company has developed its relational capabilities so it is be able to establish routines for interacting with each of these groups and if necessary to create tools for facilitating access to each of them.

Given this context, companies will, increasingly, have to evaluate the possibility to innovate openly and cooperatively in order to define their innovation strategies, once the current paradigm of innovation converges not only for the generation of innovative products and processes, but also for dynamic creation and renovation of solutions and business models, through the use and sharing of ideas that are dispersed globally. The challenge focuses, however, on the ability to manage the relational capability, involving not only the activities of creating, sharing and trading of knowledge and technologies in the headquarters and / or the subsidiaries, but also examines the relationship established with external sources of technology dispersed globally.

\section{Cooperability:Trajectory and Technological Inputs}

Even as a frontier theme, it was possible to identify in the literature the potential determinants of cooperability, synthesized in this work as "elements of technological trajectory" and "technological inputs." The elements of the trajectory approach the intensity of the experience in R\&D and cooperation and the degree of importance of the strategies for capacity building for innovation that were adopted throughout its corporate history. Technological inputs are associated with business drivers of open innovation in the medium and long term, including investment in R\&D, sales of new products and breadth of the portfolio of innovation projects (internal, national cooperation and international cooperation). The following literature presents the theoretical base that supported the research hypotheses, considering the elements of the trajectory and technological inputs that can affect the dynamic capability of innovation and cooperation. Veugelers and Cassiman (2005) showed that the trajectory of R\&D positively affects the probability of establishing collaborations with universities. Bercovitz and Feldman (2006) concluded that the continuous development of research activities along the business history is positively related to establishing relationships with universities. Laursen and Salter (2004) and Petruzzelli (20II) suggested that companies that accumulated experience in open innovation are more likely to collaborate with universities. It follows that internal experience in R\&D can affect the results of cooperability, so we formulate the following null hypotheses:
(HOI) The accumulated experience in R\&D in the headquarters does not determine the outcome of cooperability;

(H02) The accumulated experience in R\&D in foreign subsidiaries does not determine the outcome of cooperability.

Authors such as Sampson (2005), and Hoang Rothaermel (2005 and 2010) and Lai et al. (2010) also found that one of the most important determinants of the performance of partnerships focused on innovation is the experience in cooperating. Learning from the old partnership, a company refines its cooperation mechanisms, modifies their interactions, and reconfigures the allocation of resources to achieve subsequently better performance in future partnerships (Rosenkopf and Lavie, 2006).As the company institutionalize the various experiences in routines for cooperation and expand its knowledge base with regard to the implementation of cooperation, a company can then anticipate and respond to partnerships contingencies (Kim and Song, 2007; Bruneel et al., 2010 ). Given this context, it follows that the experience in cooperation may affect the results of cooperability, and we formulate the following null hypotheses:

(H03) The accumulated experience in national cooperation does not determine the outcome of cooperability;

(H04) The accumulated experience in international cooperation does not determine the outcome of cooperability.

In a complementary way, Chiaroni et al. (20II) and Ferro (20I0) showed that successful innovative firms have adopted, along the corporate trajectory, strategies for building capacities in the short, medium and long term, such as: the change in the organizational structure with the creation of independent organizational units dedicated to the management of internal R\&D and open innovation projects (West and Gallagher, 2008), the development of internal networks capable of accessing and integrating knowledge acquired externally (O'Connor, 2008), the creation of interorganizational networks (or external), which should act as an enabler of the company with respect to knowledge, innovations and ideas in and out flows (O'Connor, 2008), the development of a pilot project that will serve as a field test for the procedures of open innovation that later will be tuned, accepted and expanded throughout the organization (and Engeroff Balestrin, 2008), and finally exploitation of the knowledge generated within and outside the company to develop and exploit innovation, involving both the use of platforms and tools of information and communication technology, as the adoption of appropriate management of intellectual property (Chesbrough et al., 2008). Thus, it is expected that capacity building strategies for innovation can affect the results of the cooperability, which will be tested using the following null hypothesis: 
(H05) The degree of relevance of the strategies of technological capacity building does not determine the outcome of cooperability.

Finally, authors like Asakawa (20I0), Bruneel et al. (20I0), Chiaroni et al. (20II) and Gassmann et al. (20l0) report that certain enterprise technological inputs act as drivers of open innovation in the medium and long term, such as own investments in R \&D; prospection of external sources of investment for innovation; maintenance and renewal of the portfolio of new products and the corresponding revenues; breadth of the portfolio of internal and cooperative innovation projects, involving national and international partners. Based on this discussion we formulated the following null hypotheses:

(H06) The level of investment in R\&D does not determine the outcome of cooperability;

(H07) The percentage of revenues arising from new products determines results cooperability;

(H08) The number of innovation projects developed internally does not determine the outcome of cooperability;

(H09) The number of innovation projects developed with local partners does not determine the outcome of cooperability;

( $\mathrm{HOIO})$ The number of innovation projects developed with international partners does not determine the outcome of cooperability;

( $\mathrm{HOI}$ I) The number of innovation projects developed with national and international partners does not determine the outcome of cooperability.

\section{Method}

The research was quantitative, as we sought to verify the previously formulated hypotheses and identify the existence of relationships between variables (Lima, 2008). We used the survey method, which according to Kerlinger (1980), seeks to determine the incidence and distribution of population characteristics and opinions of people, obtaining and studying the characteristics and opinions of samples that presumably represent those populations.

The research universe was represented by 166 industrial, commercial and service providers BMN with production units or sales units abroad, identified from secondary sources of evidence, such as Project GINEBRA (Business Management for the Internationalization of Brazilian Companies), the Dom Cabral Foundation, the Valor Economico database and SOBEET (Brazilian Society for Studies of Transnational
Corporations and Economic Globalization). From this universe we made a stratification to meet the scope of the research and then we identified the BMN which actually owned international R\&D units or developed cooperative projects with foreign STI in the last three years. To accomplish this stratification we established telephone contact with those responsible for the areas of R\&D or Engineering. We also visited the institutional websites of the BMN and analyzed the Annual Reports of the BMN which are available on the CVM website (Brazilian Securities Exchange Commission). The stratification resulted in I 45 BMN which internationalized internal activities or cooperative R\&D and, of that total, 135 MNB expressed interest in participating in the research. We sent a structured questionnaire for the sample of 135 $\mathrm{BMN}$, in which we used predominantly a Likert scale of seven points, starting with I and ending with score 7, and presented statements in order to obtain the perception and I or opinion of respondents about the factors determining the dynamic ability to cooperate locally and globally. The questionnaire was available on the web, to facilitate the access of companies, and also in Word format. Then, directors or coordinators of R\&D and Innovation located at BMN headquarters received the invitation to the survey via e-mail. We performed data analysis using bivariate and multivariate statistical techniques, processed by software SPSS (Statistical Package for Social Sciences) version 17.0. We run the following statistical tests: Cronbach's alpha, factorial analysis, correlation, principal component analysis and multiple regression (Hair et al., 2005), whose characteristics are presented below.

Cronbach's alpha is a coefficient developed to measure the reliability of a test (or scale) and ranges from 0 to I, and the closer to 0 , the less reliable the scale is and the closer to I, the more reliable.A major application of this coefficient occurs in Item Response Analysis (IRA informs the extent to which a set of questions well describes a feature), where the coefficients above $70 \%$ are considerable acceptable (Cronbach, (95I).

In turn, the factorial analysis, according to Kerlinger (1980), consists in an analytical method to determine the number and type of variables that underlie a large number of variables or measurements. This technique allows the representation of relationships between variables, by means of factors that constitute a small set of dimensions that summarize the variables analyzed, with minimal loss of information.

About the correlation coefficients, we note that ones most applied to continuous and ordinal numerical scales variables are the Pearson and Spearman. The first is used when the variables are continuous scale and present a normal behavior. The second when the variables are ordinal scale, different scales or very high degree of variance. Although there 
are prerequisites for the applicability of each coefficient, these can be arbitrarily used as a primary indicator of an unknown relationship between variables and, in most cases, do not show very different values when applied together (Pagano, 2004).

Particularly the Spearman correlation coefficient is a nonparametric statistical metric to measure the degree of correlation between two variables. Being a nonparametric method, this coefficient is based on rank's (positions) for measuring the relationship between the variables, taking values from -I to I (the closer of the ends, the higher the level of correlation, either positive or negative). This coefficient also tests if the correlation coefficient hypothesis is equal to zero (0), then being rejected at a level of predetermined significance (5\% in this case) (Pagano, 2004).

The linear regression, extension of correlation analysis, aims to describe the variation of a variable (dependent) subject to the variation of one or more variables (independent I explanatory). Regression models with one explanatory variable are called Simple Linear Regression Models and models with more than one explanatory variable are called Multiple Linear Regression Models (Hair et al., 2005). To evaluate the quality of the regression model and to choose the best model is used the R-square which measures how the variability of the dependent variable (response) is explained by the model, varying from 0 to I (the higher the better ). The assumption that the residuals (difference between the values expected by the model and the observed values) are normally distributed with mean 0 and variance $\sigma 2$ must be met in order for the model to be valid, a hypothesis tested by means of the Shapiro-Wilk test at a level significance preestablished.

The linear regression model is given by: where $Y$ is the observation of the dependent variable, $\eta$ is a constant, $\alpha$ the effect of the first variable, $\beta$ is the effect of the second variable and $\varepsilon$ is the random error associated with the model, with distribution $N(0, \sigma 2)$ (Hair et al., 2005).

It is also worth noting that the principal components analysis is linked to the explanation of the covariance structure through a few linear combinations of original variables in the study and aims to facilitate the interpretation of the analysis and the reduction of the original dimension. This facility provided by the components (or factors) is given by its composition, factor loadings of each original variable representing the correlation between them and the respective component. Moreover, the components have eigenvalues indicating how each explains the total original variability. We used Cronbach's alpha as a measure of agreement between the factor generated (component) and the primary variables.

\section{INDEPENDENT VARIABLES}

Technological Trajectory

Practices of open innovation outflows capacity*

Practices of open innovation inflows capacity*

Practices of internal and cooperative R\&D capacity*

Years of experience in R \& D in the headquarters **

Years of experience in R \& D in the foreign subsidiaries**

Years of experience in national cooperation**

Years of experience in international cooperation**

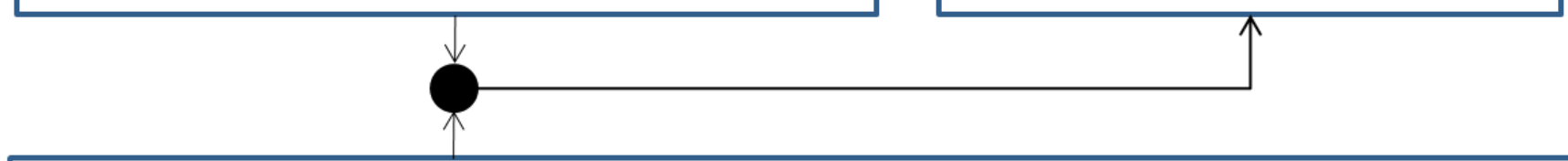

\section{INTERVENIENTS VARIABLES}

\section{Technological Inputs}

Investment in R\&D **

Revenues from new products**

Number of innovation projects developed internally $* *$

Number of innovation projects developed with national partners **

Number of innovation projects developed with international partners**

Number of innovation projects developed with national and international partners**

Figure I: Research Model.

Notes: *Variables composed using Likert scale ( $\mathrm{I}$ to reduced frequency or importance to 7 for high frequency or importance);

** Dummy variables of the regression models.

ISSN: 07 I8-2724. (http://www.jotmi.org)

Journal of Technology Management \& Innovation (c) Universidad Alberto Hurtado, Facultad de Economía y Negocios. 
Finally, the research model that reflects the theoretical framework is presented (Figure I), and also translates the expectations of the researchers in clarifying the research hypotheses that have been set in section 2 .

\section{Results}

\section{Profile of the BMN}

From the total 135 companies participating in the survey, it was found that $75 \%$ are industrial companies, $23 \%$ are service providers and only $4 \%$ are commercial enterprises. Furthermore, it was found that $52.5 \%$ employed over 500 employees, whose gross operating revenue in $201 \mathrm{I}$ was over 150 million dollars, indicating that the larger companies with higher revenues were also those with the highest number of employees in 2010 (Table I).
On the international presence of the BMN studied, it was found that cases with high productive experience in Brazil (above 53 years) were also cases with high productive experience abroad (Pearson chi-square $=7.345, \alpha=0.082$ ). These results showed that there is an association between national productive experience, international productive experience and the number of foreign subsidiaries, so the larger the number of subsidiaries, the experience was highest international production (Pearson chi-square $=10.345, \alpha=0.047$ ) . These results showed that there is an association between the experience productive national, international production experience and the number of foreign subsidiaries, ie, the more mature BMN and with greater international presence are also those that most accumulated production experience in the national context (Tables 2 and 3 ).

\begin{tabular}{|c|c|c|c|c|c|}
\hline & & \multicolumn{3}{|c|}{ Number of employees in Brazil (\%) } & \multirow[t]{2}{*}{ Total $(\%)$} \\
\hline & & Until 99 & From 100 to 499 & Over 500 & \\
\hline \multirow{3}{*}{$\begin{array}{l}\text { Gross operating revenue } \\
\text { in Brazil (\%) }\end{array}$} & Below US $\$ 45$ million & 17,5 & 12,5 & 7,5 & 37,5 \\
\hline & $\begin{array}{l}\text { Between US\$45 } \\
\text { million and US\$ } 150 \\
\text { million }\end{array}$ & 0 & 0 & 10 & 10 \\
\hline & Over US\$150 million & 0 & 0 & 52,5 & 52,5 \\
\hline Total (\%) & & 17,5 & 12,5 & 70 & 100 \\
\hline
\end{tabular}

Table I. BMN annual gross operating revenue and number of employees.

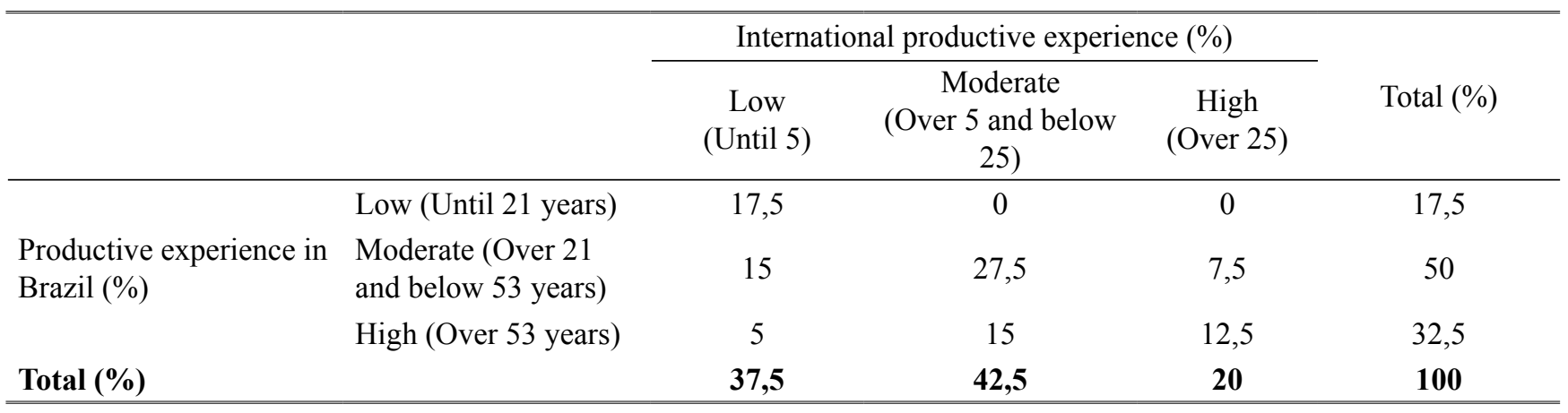

Table 2. International productive experience of the BMN according to the productive experience in Brazil*. Note: $*$ Pearson qui-square $=7,345 ; \alpha=0,082$ (significant at $10 \%$ ).

\begin{tabular}{llcccc}
\hline & & \multicolumn{2}{c}{ Number of foreign subsidiaries (\%) } & \multirow{2}{*}{ Total (\%) } \\
\cline { 3 - 4 } & & Only 1 & From 2 to 5 & Over 10 & \\
\hline
\end{tabular}

Table 3. Number of BMN foreign subsidiaries according to international productive experience*. Note: $*$ Pearson qui-square $=10,345 ; \alpha=0,047$ (significant at $5 \%$ ).

ISSN: 07 I8-2724. (http://www.jotmi.org) 
Regarding the nature of the technological partners of the BMN studied, we observed that the most relevant for innovation were national customers and national public STI, demonstrating that these companies still use basically the traditional sources of innovation that imply cooperation mechanisms already institutionalized (Table 4). The sources of innovation that require adaptation or building new cooperative mechanisms still assume a low relevance to BMN, such as international innovation networks, the national start-ups, international consultants, national non-governmental organizations, international industrial associations, international non-governmental organizations and start-ups. As pointed out by Ferro (2010), the diversity of technological partners of a company requires a more varied set of skills of cooperation, which leverages its ability to manage partnerships. In this context, the BMN should diversify their partners portfolios not only to expand the sources of innovation, but to strengthen its ability to expand their relational capacity and cooperative management skills.

Regarding the tasks often assumed by the headquarters, subsidiaries and technological partners, we found that technology foresight activities (37.5\%) and the sharing of knowledge and innovation (47.5\%) are predominantly dispersed among these actors. However, there was a strong centralization in the headquarters of technological development activities (40\%), customization of products and processes ( $45 \%)$, scoping of internal R\&D projects (57.5\%) and cooperatively (42 $5 \%$ ), selection of new technological partners (40\%), internal R\&D project portfolio management (62.5\%) and portfolio

\begin{tabular}{|c|c|c|c|c|c|c|c|c|c|c|}
\hline \multirow{2}{*}{ Categories" } & \multicolumn{7}{|c|}{ Degree of relevance $(\%)$} & \multirow{2}{*}{\multicolumn{2}{|c|}{$\mathbf{N A} \quad \mathbf{S P}$}} & \multirow{2}{*}{$\mathbf{M}$} \\
\hline & 1 & 2 & 3 & 4 & 5 & 6 & 7 & & & \\
\hline National customers & 0 & 12,5 & 2,5 & 12,5 & 22,5 & 17,5 & 32,5 & 0 & 1,68 & 5,28 \\
\hline $\begin{array}{l}\text { National public Scientific and Technological } \\
\text { Institutions }\end{array}$ & 2,5 & 10 & 5 & 5 & 15 & 27,5 & 30 & 5 & 2,09 & 5,08 \\
\hline National suppliers & 7,5 & 5 & 10 & 10 & 20 & 20 & 25 & 2,5 & 2,01 & 4,83 \\
\hline International customers & 12,5 & 17,5 & 5 & 7,5 & 15 & 20 & 20 & 2,5 & 2,25 & 4,28 \\
\hline $\begin{array}{l}\text { National private Scientific and Technological } \\
\text { Institutions }\end{array}$ & 2,5 & 17,5 & 10 & 7,5 & 20 & 22,5 & 12,5 & 7,5 & 2,13 & 4,20 \\
\hline $\begin{array}{l}\text { International public Scientific and Techno- } \\
\text { logical Institutions }\end{array}$ & 12,5 & 10 & 2,5 & 7,5 & 25 & 22,5 & 10 & 10 & 2,31 & 4,00 \\
\hline International suppliers & 20 & 5 & 10 & 17,5 & 10 & 27,5 & 7,5 & 2,5 & 2,12 & 3,98 \\
\hline National consultants & 12,5 & 17,5 & 12,5 & 7,5 & 12,5 & 22,5 & 7,5 & 7,5 & 2,20 & 3,65 \\
\hline $\begin{array}{l}\text { International private Scientific and Techno- } \\
\text { logical Institutions }\end{array}$ & 16,8 & 14,3 & 8,4 & 8,4 & 14,5 & 15,7 & 11,3 & 10,5 & 2,14 & 3,63 \\
\hline National regulators & 15 & 12,5 & 10 & 5 & 15 & 20 & 10 & 12,5 & 2,40 & 3,55 \\
\hline National industrial associations & 30 & 17,5 & 2,5 & 2,5 & 17,5 & 17,5 & 10 & 2,5 & 2,33 & 3,45 \\
\hline International regulators & 15 & 10 & 15 & 5 & 20 & 17,5 & 5 & 12,5 & 2,24 & 3,40 \\
\hline National innovation networks & 17,7 & 14,4 & 8,7 & 8,2 & 14,1 & 15,6 & 10,2 & 11,1 & 2,04 & 3,33 \\
\hline National competitors & 20 & 20 & 12,5 & 10 & 10 & 12,5 & 7,5 & 7,5 & 2,14 & 3,15 \\
\hline International competitors & 25,0 & 12,5 & 5 & 15 & 15 & 0 & 15 & 12,5 & 2,35 & 3,05 \\
\hline International innovation networks & 18 & 14,3 & 8,9 & 8,2 & 14 & 15,3 & 9,7 & 11,5 & 2,02 & 2,90 \\
\hline National start-ups & 20 & 20 & 12,5 & 2,5 & 12,5 & 5 & 12,5 & 15 & 2,33 & 2,88 \\
\hline International consultants & 15 & 27,5 & 12,5 & 10 & 15 & 5 & 0 & 15 & 1,80 & 2,53 \\
\hline National NGO’s & 25 & 12,5 & 5 & 7,5 & 7,5 & 10 & 7,5 & 25 & 2,39 & 2,45 \\
\hline International industrial associations & 35,0 & 17,5 & 7,5 & 10 & 5 & 10 & 2,5 & 12,5 & 1,99 & 2,35 \\
\hline International NGO's & 27,5 & 7,5 & 5 & 12,5 & 10 & 12,5 & 0 & 25 & 2,18 & 2,33 \\
\hline International start-ups & 22,5 & 20 & 15 & 5 & 7,5 & 7,5 & 0 & 22,5 & 1,85 & 2,10 \\
\hline
\end{tabular}

Table 4. Indicators of the degree of relevance of the nature of the technological partners for innovation. Note: NA = not applicable, SD = standard deviation $M=$ mean; * Scale used: I for 7 for reduced relevance and high relevance.

ISSN: 07 I8-2724. (http://www.jotmi.org) 
management of cooperative projects $(52.5 \%)$. The non-routine engineering activities were conducted both in the headquarters and in foreign subsidiaries in $35 \%$ of cases, while applied research has been developed in the headquarters (30\%), national technological partners (22.5\%) and dispersed among headquarters, foreign subsidiaries and national and international partners (20\%) (Table 5).

The results of the technical and managerial roles showed that the BMN leverage the international presence to identify, absorb and subsequently disseminate trends and knowledge in its network of subsidiaries and technological partners, obtaining advantages by benefiting from the global reservoirs of knowledge, what reinforces the discussions by Porto et al. (2010) and Bartlett and Ghoshal (1992) about the internationalization as a strategy to feel and explore local opportunities. However, note that these companies still focus their R\&D and innovation management in the headquarters, aiming to centralize critical mass and promote synergies with respect to the development of internal and cooperative $R \& D$ projects.

These results reinforce the findings of Chiesa (2000) and Gassmann and Zedtwitz (1999) regarding the centralization of R\&D in some central units, usually the headquarters or centers of excellence, whose critical point is the inability to develop effectively internal and cooperative R\&D activities in foreign subsidiaries which, in turn, makes not viable the

\begin{tabular}{|c|c|c|c|c|c|c|c|c|}
\hline \multirow[b]{2}{*}{ Categories } & \multicolumn{8}{|c|}{ Place where the activity is executed (\%) } \\
\hline & $\begin{array}{l}\text { Headquar- } \\
\text { tes, only }\end{array}$ & $\begin{array}{l}\text { Foreign } \\
\text { subsidiar- } \\
\text { ies, only }\end{array}$ & $\begin{array}{l}\text { Headquar- } \\
\text { ters ans } \\
\text { foreign } \\
\text { subsidiaries }\end{array}$ & $\begin{array}{c}\text { National } \\
\text { techno- } \\
\text { logical } \\
\text { partners, } \\
\text { only } \\
\end{array}$ & $\begin{array}{c}\text { Internation- } \\
\text { al tech- } \\
\text { nological } \\
\text { partners, } \\
\text { only }\end{array}$ & $\begin{array}{l}\text { Both inter- } \\
\text { national and } \\
\text { technologi- } \\
\text { cal partners }\end{array}$ & $\begin{array}{l}\text { Headquar- } \\
\text { ters, foreign } \\
\text { subsidiaries, } \\
\text { national } \\
\text { and/or } \\
\text { international }\end{array}$ & $\begin{array}{l}\text { Not appli- } \\
\text { cable }\end{array}$ \\
\hline & & & & & & & partners & \\
\hline $\begin{array}{l}\text { Foresight of } \\
\text { technological and } \\
\text { scientific trends }\end{array}$ & 32,5 & 0 & 12,5 & 2,5 & 2,5 & 10 & 37,5 & 2,5 \\
\hline $\begin{array}{l}\text { Customization } \\
\text { of products and } \\
\text { processes }\end{array}$ & 45 & 0 & 35 & 0 & 0 & 2,5 & 12,5 & 5 \\
\hline Applied research & 30 & 0 & 10 & 22,5 & 5 & 5 & 20 & 7,5 \\
\hline $\begin{array}{l}\text { Non-routine enge- } \\
\text { neering }\end{array}$ & 32,5 & 0 & 35 & 0 & 0 & 2,5 & 12,5 & 17,5 \\
\hline $\begin{array}{l}\text { Sharing of knowl- } \\
\text { edge, innovation } \\
\text { and technology }\end{array}$ & 17,5 & 0 & 12,5 & 0 & 2,5 & 10 & 47,5 & 10 \\
\hline $\begin{array}{l}\text { Technological } \\
\text { development }\end{array}$ & 40 & 0 & 22,5 & 0 & 2,5 & 5 & 25 & 5 \\
\hline $\begin{array}{l}\text { Cooperative } \\
\text { projects portfólio } \\
\text { management }\end{array}$ & 52,5 & 0 & 15 & 0 & 0 & 7,5 & 12,5 & 12,5 \\
\hline $\begin{array}{l}\text { Selection of new } \\
\text { scientific and tech- } \\
\text { nological partners }\end{array}$ & 40 & 0 & 30 & 0 & 0 & 12,5 & 10 & 7,5 \\
\hline $\begin{array}{l}\text { Scoping of coop- } \\
\text { erative projects }\end{array}$ & 42,5 & 0 & 17,5 & 0 & 0 & 2,5 & 25 & 12,5 \\
\hline $\begin{array}{l}\text { Internal R\&D } \\
\text { projects portfólio } \\
\text { management }\end{array}$ & 62,5 & 0 & 12,5 & 0 & 0 & 7,5 & 12,5 & 5 \\
\hline $\begin{array}{l}\text { Scoping of inter- } \\
\text { nal R\&D projects }\end{array}$ & 57,5 & 0 & 17,5 & 0 & 0 & 2,5 & 20 & 2,5 \\
\hline
\end{tabular}

Table 5. Role played by the headquarters, subsidiaries and technological partners.

ISSN: 07 I8-2724. (http://www.jotmi.org)

Journal of Technology Management \& Innovation (C) Universidad Alberto Hurtado, Facultad de Economía y Negocios. 
generation of a dynamic capability of technological cooperation in foreign subsidiaries and international partners networks, also known as relational capacity (Wassmer, 20l0).

Another relevant point is that the autonomy of foreign subsidiaries of BMN is still predominantly limited to the execution of non-routine engineering and technological foresight in order to adapt products and processes to the local market, which restricts the initiative of these units to effectively generate local and / or global innovations. These results converge to the discussions of Ambos and Schlegelmilch (2007), because as the operational autonomy is not effective for the foreign subsidiaries of the BMN is evident that these units will struggle to make their own decisions on cooperation with foreign companies and external organizations, which can reduce their ability to explore and manage external sources of innovation and improve their resource base and their innovative performance.

\section{Analysis of the Technological Elements Determi- nants of Cooperability Results}

A multivariate regression technique seeks to investigate the influence of each variable when they are all taken together (Hair et al., 2005). Note also that the prerequisites of the generated regressions have been met, as indicated by tests of normality (Kolmogorov-Smirnov and Shapiro-Wilk tests) and collinearity (VIF) presented in Tables II and I2. Furthermore, we point out that the coefficients of Cronbach's alpha were greater than $80 \%$, confirming that the compound variables of the study are explained by the set of categories that constitutes them (Table 6).

Hereafter, we present the factorial analysis of the compound variables:Technological Capability and Cooperability Results (Tables 7 and 8). Specifically, Table 7 makes clear that three factors explain $76 \%$ of the variance of the responses on the

\section{Compound variables}

Technological capability*

Results of Cooperability**

Table 6. Cronbach's alpha coefficient.

Notes: *Compound independent variables and **compound dependent variables using Likert scale: I for reduced frequency or importance to 7 for high frequency or importance.

\begin{tabular}{|c|c|c|}
\hline Factors* & Factor loading & $\begin{array}{l}\text { Cumulative ex- } \\
\text { plained variance }\end{array}$ \\
\hline Factor 1: Practices of open innovation outflows capacity & & $16 \%$ \\
\hline $\begin{array}{l}\text { Investment in companies with promising technologies or with potential to } \\
\text { generate them }\end{array}$ & 0,694 & \\
\hline $\begin{array}{l}\text { Exchange of technological know-how without licensing of novel technolo- } \\
\text { gies (patents) where two or more companies exchange proprietary technol- } \\
\text { ogies in order to achieve strategic objectives, without necessarily having a } \\
\text { licensing agreement like cross-licensing }\end{array}$ & 0,643 & \\
\hline Licensing of patents and intellectual property to other companies & 0,582 & \\
\hline $\begin{array}{l}\text { Creation of a new company, a spin-off or a joint venture, to disseminate and } \\
\text { share technological competences }\end{array}$ & 0,486 & \\
\hline Factor 2: Practices of open innovation inflows capacity & & $32 \%$ \\
\hline Technological benchmarking of competitors / suppliers & 0,786 & \\
\hline $\begin{array}{l}\text { Acquisitions of companies to optimize efforts in R\&D and innovation, espe- } \\
\text { cially start-ups }\end{array}$ & 0,683 & \\
\hline Purchase of external technologies (patented or not) & 0,673 & \\
\hline Mergers between companies to optimize efforts in $R \& D$ and innovation & 0,635 & \\
\hline $\begin{array}{l}\text { Funding of research centers to gain agility in R\&D and add external ideas } \\
\text { and efforts for research activities }\end{array}$ & 0,561 & \\
\hline
\end{tabular}




\begin{tabular}{|l|c|}
\hline Factor 3: Practices of internal and cooperative R\&D capacity & \\
\hline $\begin{array}{l}\text { Creating in the headquarters an area or unit dedicated to the development of } \\
\text { R\&D and other innovative activities }\end{array}$ & 0,945 \\
$\begin{array}{l}\text { Training and continuous capacity building of R\&D staff } \\
\text { Hiring specialized consultants in R\&D and innovation }\end{array}$ & 0,904 \\
$\begin{array}{l}\text { Development of an open innovation pilot project to define and, subsequently, } \\
\text { align procedures and administrative routines }\end{array}$ & 0,874 \\
$\begin{array}{l}\text { Establishment of continuous partnerships with national STI } \\
\text { Creation in foreign subsidiaries of an area or unit dedicated to the develop- } \\
\text { ment of R\&D and other innovative activities }\end{array}$ & 0,851 \\
$\begin{array}{l}\text { Establishment of continuous partnerships with international STI } \\
\text { Conducting cooperative projects with defined scope, focused on research } \\
\text { activities that precede the stages of creating and developing of new products } \\
\text { and technologies }\end{array}$ & 0,821 \\
$\begin{array}{l}\text { Conducting short-term cooperative projects focused on the development of } \\
\text { existing technology, a product or a specific product line already. }\end{array}$ & 0,728 \\
$\begin{array}{l}\text { Conducting cooperative projects with open scope, being possible to can set } \\
\text { up a network, in order to investigate a problem or a common technological } \\
\text { challenge and generate results that can serve as a basis to support future } \\
\text { research and technological developments }\end{array}$ & 0,626 \\
\hline
\end{tabular}

Table 7. Factors of importance of technological strategies adopted by the BMN.

Note: $*$ KMO $=0.758$, Chi-square $=882.345, \mathrm{p}=1 \%$.

\begin{tabular}{|c|c|c|}
\hline Factors* & Carga fatorial & $\begin{array}{l}\text { Variância } \\
\text { explicada }\end{array}$ \\
\hline Fator 1: Technological results of cooperability & & $32 \%$ \\
\hline Generating new products and processes & 0,769 & \\
\hline Emergence of new Technologies & 0,746 & \\
\hline Filing of patent applications & 0,662 & \\
\hline Generation of new methods for marketing & 0,643 & \\
\hline Application for registration of trademarks & 0,628 & \\
\hline Application for software registration & 0,583 & \\
\hline Technology licensing & 0,503 & \\
\hline Emergence of new business & 0,453 & \\
\hline Generating new organizational methods & 0,447 & \\
\hline Factor 2: Managerial results of cooperability & & $85 \%$ \\
\hline Establishment of new technological partnerships & 0,912 & \\
\hline Meeting deadlines & 0,806 & \\
\hline Budgets compliance & 0,824 & \\
\hline Achievement of objectives & 0,752 & \\
\hline
\end{tabular}

Table 8. Factors the frequency with which the results were achieved in cooperative projects. Note: $*$ KMO $=0.967$, Chi-square $=957.368, \mathrm{p}=1 \%$. 
importance of technological strategies adopted by BMN, with $1 \%$ significance. These explanatory factors and their constituent categories enabled the following classification: (factor I) Strategies to empower the outflows of open innovation; (factor 2) Strategies to empower the inflows of open innovation, and (factor 3) Strategies to build capability in internal and cooperative R\&D. Note also that the greater degree of explanation is linked to the factor $3(44 \%)$, ie, the strategies to build capability in internal and cooperative R\&D, followed by the factors I (16\%) and 2 (16\%) involving, respectively, the flows of output and input of knowledge and technologies provided by open innovation.

From the results shown in Table 8, we found that two factors explain $85 \%$ of the variance of the responses regarding the frequency with which the results were achieved in cooperative projects from partnerships of BMN, with $1 \%$ significance. The analysis of the generated factors, and their respective categories, resulted in the following classification: (factor 1) Technological results of cooperability (factor 2) Managerial results of cooperability. The greater degree of explanation is linked to the factor 2 (53\%), ie, the range of managerial outcomes in cooperative projects, followed by factor I (32\%) which is linked to technological results.

It is worth mentioning that after we generated the factors of compound variables highlighted in Table 7 and 8, they were subjected to correlation analysis to prevent regressions from the incidence of multicollinearity problems (correlated independent variables, with $r \geq 80 \%$ ) and also eliminate independent variables with tiny correlation with the dependent variables $(r<10 \%)$. These analyzes were also performed with the dummy variables (tables 9 and 10 ).
The correlation analysis in Table 9 shows a high correlation between the following factors: (X2) Practices of capacity building for inflows of open innovation and (X3) Practices of capacity building for internal and cooperative R\&D. In order to mitigate multicollinearity, we eliminated from the regressions the factors highly correlated and with lower correlation with the dependent variable, such as: the $X 3$ factor in the regression of (YI) Results of Technological Cooperability and factor $X 2$ in the regression of (Y2) Results of Managerial Cooperability.

The results in Table 10 indicated a high correlation between the dummy variables $(X 7)$ Number of innovation projects developed with local partners and (X8) Number of innovation projects developed with international partners. In order to mitigate multicollinearity, we eliminated from the regressions the dummy variables highly correlated and with lower correlation with the dependent variable, such as: the $X 7$ variable in the regression of $(Y I)$ Technological results of cooperability and the $X 8$ variable in the regression of (Y2) Managerial results of cooperability.

Regarding the regressions, five models were generated for each dependent variable, whose coefficients presented in Tables $\mathrm{II}$ and $\mathrm{I} 2$ indicate the explanatory power of the independent variables and the dummy variables (elements of the trajectory and technological inputs) on the dependent variables of the study (technological and managerial results of cooperability). Among the regressions performed, the ones that showed the best explanatory power were calculated after testing for multicollinearity (regression I), resulting in an adjusted R-squared of $86 \%$ for the technological results of cooperability (Table II) and $75 \%$ for the managerial results of cooperability (Table I2).

\begin{tabular}{lllccc}
\hline & & X1 & X2 & X3 \\
X1 & Practices of open innovation outflows capacity & & \\
\hline X2 & Practices of open innovation inflows capacity & $12 \%$ & & \\
\hline X3 & Practices of internal and cooperative R\&D capacity & $71 \%$ & $88 \%$ & \\
\hline Y1 & Technological results of cooperability & $\mathbf{2 2 \%}$ & $\mathbf{2 8 \%}$ & $\mathbf{1 1 \%}$ \\
Y2 & Managerial results of cooperability & $\mathbf{1 5 \%}$ & $\mathbf{1 0 \%}$ & $\mathbf{8 2 \%}$ \\
\hline
\end{tabular}

Table 9. Pearson Correlation Coefficient $(r)$ between the independent compound variables $(X)$ against the dependent variables $(\mathrm{Y})$. 


\begin{tabular}{|c|c|c|c|c|c|c|c|c|c|c|c|}
\hline $\mathbf{X} 4$ & Investment in $\mathrm{R} \& \mathrm{D}$ & $\mathrm{X} 4$ & $\mathrm{X5}$ & X6 & $\mathrm{X} 7$ & X8 & X9 & $\mathrm{X} 10$ & $\mathrm{X} 11$ & $\mathrm{X} 12$ & $\mathrm{X} 13$ \\
\hline $\mathbf{X 5}$ & Revenues from new products & $21 \%$ & & & & & & & & & \\
\hline X6 & $\begin{array}{l}\text { Number of innovation projects } \\
\text { developed internally }\end{array}$ & $-13 \%$ & $-10 \%$ & & & & & & & & \\
\hline $\mathbf{X} 7$ & $\begin{array}{l}\text { Number of innovation projects } \\
\text { developed with national } \\
\text { partners }\end{array}$ & $-28 \%$ & $-10 \%$ & $73 \%$ & & & & & & & \\
\hline X8 & $\begin{array}{l}\text { Number of innovation projects } \\
\text { developed with international } \\
\text { partners }\end{array}$ & $-28 \%$ & $-10 \%$ & $73 \%$ & $100 \%$ & & & & & & \\
\hline X9 & $\begin{array}{l}\text { Number of innovation projects } \\
\text { developed with national and } \\
\text { international partners }\end{array}$ & $3 \%$ & $-10 \%$ & $24 \%$ & $22 \%$ & $22 \%$ & & & & & \\
\hline X10 & $\begin{array}{l}\text { Years of experience in } R \& D \text { in } \\
\text { the headquarters }\end{array}$ & $-11 \%$ & $28 \%$ & $23 \%$ & $14 \%$ & $14 \%$ & $0 \%$ & & & & \\
\hline X11 & $\begin{array}{l}\text { Years of experience in } R \& D \text { in } \\
\text { the foreign subsidiaries }\end{array}$ & $-10 \%$ & $17 \%$ & $22 \%$ & $31 \%$ & $31 \%$ & $1 \%$ & $37 \%$ & & & \\
\hline X12 & $\begin{array}{l}\text { Years of experience in nation- } \\
\text { al cooperation }\end{array}$ & $21 \%$ & $25 \%$ & $30 \%$ & $13 \%$ & $13 \%$ & $13 \%$ & $52 \%$ & $16 \%$ & & \\
\hline X13 & $\begin{array}{l}\text { Years of experience in interna- } \\
\text { tional cooperation }\end{array}$ & $1 \%$ & $17 \%$ & $22 \%$ & $16 \%$ & $16 \%$ & $31 \%$ & $59 \%$ & $32 \%$ & $50 \%$ & \\
\hline Y1 & $\begin{array}{l}\text { Technological results of } \\
\text { cooperability }\end{array}$ & $50 \%$ & $42 \%$ & $67 \%$ & $21 \%$ & $38 \%$ & $59 \%$ & $40 \%$ & $55 \%$ & $62 \%$ & $43 \%$ \\
\hline Y2 & $\begin{array}{l}\text { Managerial results of coop- } \\
\text { erability }\end{array}$ & $13 \%$ & $-15 \%$ & $-26 \%$ & $-31 \%$ & $-21 \%$ & $-16 \%$ & $-15 \%$ & $23 \%$ & $-21 \%$ & $12 \%$ \\
\hline
\end{tabular}

Table 10. Pearson correlation coefficient between the dummy variables $(\mathrm{X})$ against the dependent variables $(\mathrm{Y})$. 


\begin{tabular}{|c|c|c|c|c|c|c|c|c|c|c|c|}
\hline \multicolumn{12}{|c|}{ Y1 (dependent variable) = TECHNOLOGICAL RESULTS OF COOPERABILITY } \\
\hline & & \multicolumn{2}{|c|}{$1^{\text {a }}$ Regression } & \multicolumn{2}{|c|}{$2^{\text {a }}$ Regression } & \multicolumn{2}{|c|}{$3^{\text {a }}$ Regression } & \multicolumn{2}{|c|}{$4^{\mathrm{a}}$ Regression } & \multicolumn{2}{|c|}{$5^{\text {a }}$ Regression } \\
\hline $\begin{array}{l}\text { Independents and } \\
\text { Dummy }\end{array}$ & $\begin{array}{l}\text { Operational definitions } \\
\text { of the variables and } \\
\text { factors }\end{array}$ & \multicolumn{2}{|c|}{$\begin{array}{l}\text { After first multicol- } \\
\text { linearity test }\end{array}$} & \multicolumn{2}{|c|}{ Stepwise $5 \%$} & \multicolumn{2}{|c|}{ Stepwise $10 \%$} & \multicolumn{2}{|l|}{$\begin{array}{l}\text { Stepwise } \\
15 \%\end{array}$} & \multicolumn{2}{|c|}{$\begin{array}{l}\text { After principal } \\
\text { component }\end{array}$} \\
\hline & & $\begin{array}{l}\text { Coeffi- } \\
\text { cients }\end{array}$ & VIF & $\begin{array}{l}\text { Coeffi- } \\
\text { cients }\end{array}$ & VIF & $\begin{array}{l}\text { Coeffi- } \\
\text { cients }\end{array}$ & VIF & $\begin{array}{l}\text { Coeffi- } \\
\text { cients }\end{array}$ & VIF & $\begin{array}{l}\text { Coeffi- } \\
\text { cients }\end{array}$ & VIF \\
\hline Constant & & 1,761 & - & $0,503 *$ & - & $2,234^{*}$ & - & $2,367 *$ & - & $4,675^{*}$ & \\
\hline \multirow{2}{*}{$\begin{array}{l}\text { Independent variables } \\
\text { of technological } \\
\text { trajectory }\end{array}$} & $\begin{array}{l}\mathrm{X} 1=\text { Strategies of open } \\
\text { innovation outflows } \\
\text { capacity }\end{array}$ & 1,361 & 1,471 & - & 1,289 & - & 1,264 & - & 1,456 & - & 1,521 \\
\hline & $\begin{array}{l}\mathrm{X} 2=\text { Strategies of open } \\
\text { innovation inflows } \\
\text { capacity }\end{array}$ & $1,021^{*}$ & 1,032 & - & 1,267 & - & 1,361 & - & 1,321 & - & 1,269 \\
\hline \multirow{5}{*}{$\begin{array}{l}\text { Dummy of technologi- } \\
\text { cal inputs }\end{array}$} & $\mathrm{X} 4=$ Investment in $\mathrm{R} \& \mathrm{D}$ & $0,307 * * *$ & 1,201 & - & 1,356 & - & 1,390 & $0,230 * * *$ & 1,211 & - & 1,445 \\
\hline & $\begin{array}{l}\mathrm{X} 5=\text { Revenues from new } \\
\text { products }\end{array}$ & 0,201 & 1,378 & - & 1,389 & - & 1,467 & - & 1,356 & - & 1,423 \\
\hline & $\begin{array}{l}\mathrm{X} 6=\text { Number of innova- } \\
\text { tion projects developed } \\
\text { internally }\end{array}$ & $0,457 * * *$ & 1,211 & - & 1,349 & - & 1,378 & $0,534 * * *$ & 1,208 & - & 1,352 \\
\hline & $\begin{array}{l}\mathrm{X} 8=\text { Number of innova- } \\
\text { tion projects developed } \\
\text { with international } \\
\text { partners }\end{array}$ & 0,894 & 1,456 & - & 1,331 & - & 1365 & - & 1,306 & - & 1,470 \\
\hline & $\begin{array}{l}\mathrm{X} 9=\text { Number of innova- } \\
\text { tion projects developed } \\
\text { with national and interna- } \\
\text { tional partners }\end{array}$ & $0,286 * * *$ & 1,236 & - & 1,376 & - & 1,402 & $0,346^{* * *}$ & 1,121 & - & 1,387 \\
\hline \multirow{4}{*}{$\begin{array}{l}\text { Dummy of technologi- } \\
\text { cal trajectory }\end{array}$} & $\begin{array}{l}\mathrm{X} 10=\text { Years of expe- } \\
\text { rience in } \mathrm{R} \& \mathrm{D} \text { in the } \\
\text { headquarters }\end{array}$ & $1,741 * *$ & 1,141 & - & 1,312 & - & 1,356 & $1,504 * *$ & 1,124 & - & 1,389 \\
\hline & $\begin{array}{l}X 11=\text { Years of expe- } \\
\text { rience in R\&D in the } \\
\text { foreign subsidiaries }\end{array}$ & 0,708 & 1,329 & - & 1,287 & - & 1,352 & - & 1,403 & - & 1,254 \\
\hline & $\begin{array}{l}\text { X12 = Years of ex- } \\
\text { perience in national } \\
\text { cooperation }\end{array}$ & $0,983 * *$ & 1,202 & - & 1,320 & - & 1,301 & $0,857 * *$ & 1,187 & - & 1,356 \\
\hline & $\begin{array}{l}\text { X13 = Years of expe- } \\
\text { rience in international } \\
\text { cooperation }\end{array}$ & 0,512 & 1,431 & - & 1,483 & - & 1,462 & - & 1,553 & - & 1,482 \\
\hline \multicolumn{2}{|l|}{ Principal component } & - & - & - & - & - & - & - & & $0,641^{*}$ & \\
\hline \multicolumn{2}{|l|}{ Adjusted R square } & 0,867 & & 0,619 & & 0,731 & & 0,749 & & 0,587 & \\
\hline \multicolumn{2}{|l|}{ Kolmogorov-Smirnov } & $0,156^{*}$ & & $0,136^{* *}$ & & $0,141 *$ & & $0,147^{*}$ & & $0,131^{* *}$ & \\
\hline \multicolumn{2}{|l|}{ Shapiro-Wilk } & $0,982 *$ & & $0,957 * *$ & & $0,971^{*}$ & & $0,966^{*}$ & & $0,942 * *$ & \\
\hline
\end{tabular}

Table II. Regressions results for the dependent variable technological results of cooperability. Note: *p 1\%; **p 5\%; ***p $10 \%$. 


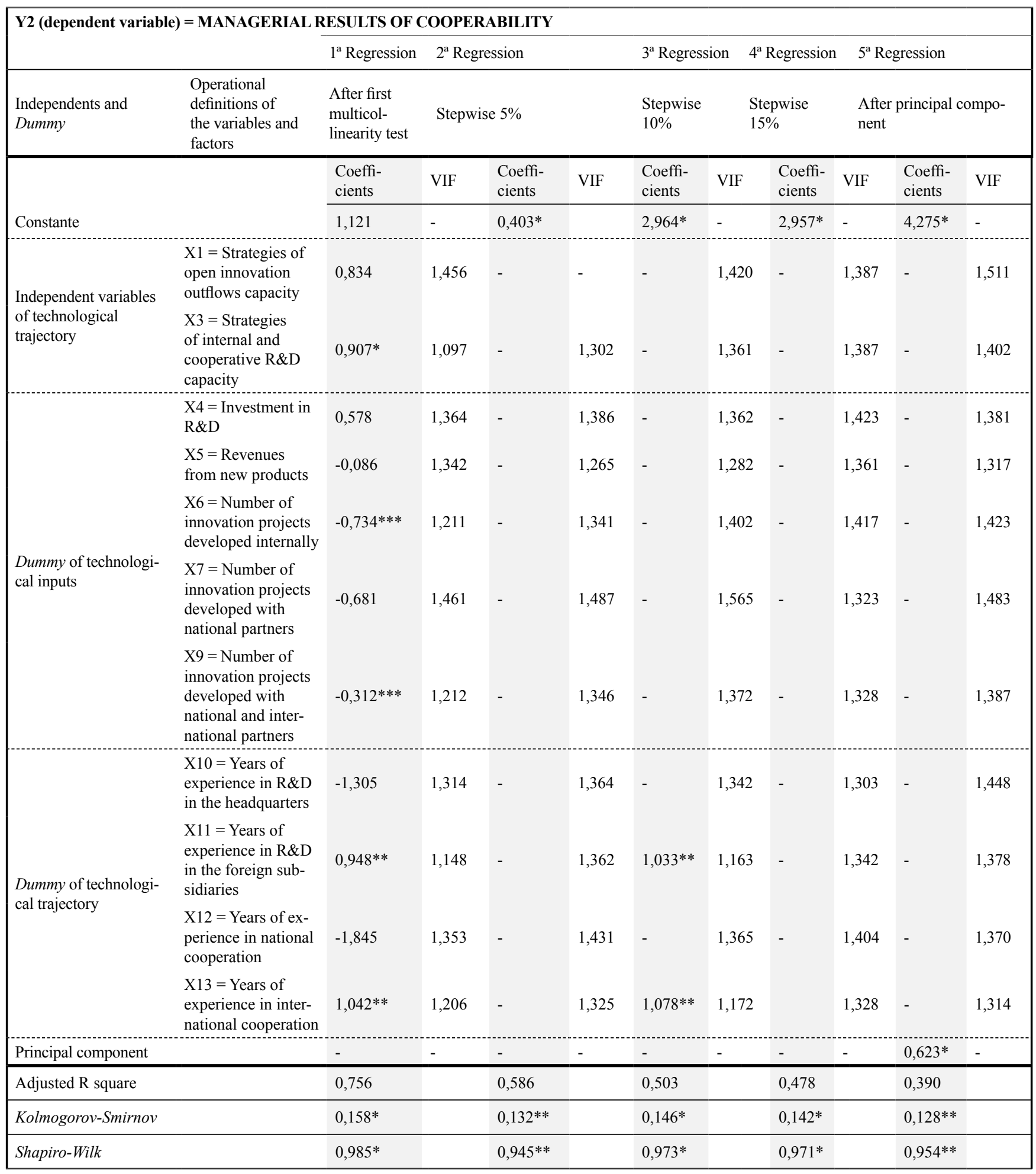

Table 12. Regression results for the dependent variable managerial results of cooperability. Note: $*_{p}$ I\%; **p 5\%; ***p I0\% 
Specifically on the determinants of cooperability results, we found based on the generated regressions that the capacity building strategies for inflows of open innovation are relevant to the technological results, with significance of $1 \%$ in the first regression (Table II). For the managerial results, we found that the capacity building strategies for internal and cooperative R\&D assume greater importance, with I\% significance also in the first regression (Table I2). From these results, we can infer that the technological capacity building strategies adopted by the BMN to enhance the inflow of open innovation and leverage internal and cooperative R\&D determine, respectively, the technological and managerial results of cooperability, rejecting $\mathrm{H} 05$, so the degree of relevance of the technological capacity building determines the results of cooperability in the model analyzed.

About the dummy variables of technological inputs, we found that the percentage of gross sales invested in R\&D, the number of innovation projects developed internally and the number of innovation projects developed with national and international partners are relevant to the technological results of cooperability, being the three variables that were significant at $10 \%$ in the first and fourth regression (Table II). From these results, we can infer that the greater the investment in R\&D and the larger the portfolio of internal and national and international cooperation innovation projects, the greater will be the technological results obtained in cooperability, rejecting the hypotheses $\mathrm{H} 06, \mathrm{H} 08$ e $\mathrm{HOII}$. Therefore, we concluded that the level of investment in R\&D determines the results of cooperability, the number of innovation projects developed internally determines the results of cooperability, and the number of innovation projects developed with national and international partners determines the results of cooperability.

For the managerial results of cooperability, the most relevant dummy variables of technological inputs were the number of innovation projects developed internally and the number of innovation projects developed with national and international partners, both with $10 \%$ significance in the first regression (Table 12). That led to the rejection of the hypothesis $\mathrm{H} 08$, showing that the number of innovation projects developed internally determines the results of cooperability in the model analyzed. We also rejected $\mathrm{HOII}$, so the number of innovation projects developed with national and international partners determines the results of cooperability in the model in question. However, we observed a negative correlation, indicating that the size of the internal project portfolio and the size of the national and international cooperation project portfolio negatively determine the results of managerial cooperability, ie, the greater these portfolios, the lower the frequency of results that translate the managerial efficiency of the cooperative process.
Regarding the dummy variables of the trajectory of cooperability, we found that the experience in R\&D in the headquarters and experience in national cooperation are relevant to the technological results of cooperability, with significance level of $5 \%$ in the first and fourth regression (Table II). So we reject the hypothesis $\mathrm{HOI}$, indicating that the years of experience in R\&D in the headquarters determine the results of cooperability in the model analyzed. We also rejected $\mathrm{H} 03$ so we conclude that the years of accumulated experience in national cooperation determine the results of cooperability in the model in question. For managerial results of cooperability, experience in R\&D in foreign subsidiaries and experience in international cooperation assumed greater significance, with significance level of $5 \%$ in the first and third regression (Table 12). So we reject the hypothesis $\mathrm{H} 02$, showing that the years of accumulated experience in R\&D in foreign subsidiaries determine the results of cooperability in the model analyzed. We also reject $\mathrm{HO4}$; we found that the years of experience in international cooperation determine the results of cooperability in the model in question.

It is worth noting that the greater the experience in R\&D in foreign subsidiaries and international cooperation, more frequent are the managerial results of cooperability, reinforcing the relevance of the "learning function" in the construction of relational capacity (Singh, 2007; Heimeriks et al. , 2007), which may in part be explained by the exposure of the BMN to foreign technological partners who demanded over the years the creation or adaptation of cooperative practices specific to the international context and that, in turn, generated to learning $\mathrm{BMN}$ in relation to the management of the cooperation (Lai et al., 20 I0; Petruzzelli, 20II).

Finally, we note that the other variables were not statistically significant, so they do not determine the technological and managerial results of cooperability. In the fifth regression, we calculated principal component from the variability of all the original variables. We verified their impact on the technological and managerial results of cooperability. However, the principal components generated, despite being significant at $1 \%$, had a low explanatory power when compared to the other regressions performed ( $58 \%$ for the technological results of cooperability in Table II and 39\% for the managerial results of cooperability in Table 12).

\section{Conclusion}

From the results, we found that the more mature in the international context and with the largest number of foreign subsidiaries $\mathrm{BMN}$ are also those who have accumulated more productive experience in the national context, indicating the existence of a positive synergy between the national and international productive experience. 
About the technical and managerial roles of internal and cooperative R\&D, the results showed that the BMN leverage the international presence to identify, absorb and subsequently disseminate trends and knowledge in its network of subsidiaries and technological partners, obtaining advantages by benefiting from the global reservoirs of knowledge. However, note that the BMN also centralize R\&D and innovation management in headquarters, in order to concentrate the critical mass and promote synergies with respect to the development of internal and cooperative R\&D projects. Another relevant point is that the autonomy of foreign subsidiaries of BMN is still predominantly limited to the execution of non-routine engineering and technological foresight in order to adapt products and processes to the local market, which restricts the initiative of these units to effectively generate local and/or global innovations, internal or cooperatives, weakening their ability to explore and manage external sources of innovation and improve their resource base and their overall innovative performance.

Regarding the impact of the elements of the trajectory on the technological results of cooperability it is noting worth the experience in R\&D in headquarters, and for managerial results of cooperability the accumulated experience in $R \& D$ in foreign subsidiaries and international cooperation, showing that the greater the experience in R\&D in headquarters the most effective the technological results, and the greater the accumulated experience in R\&D in foreign subsidiaries and international cooperation the more effective will be the managerial results of cooperability. Furthermore, it was found that the greater the degree of relevance of technological capacity building strategies, the results will be more effective both technological and managerial (Figure 2).

On inputs that determine the technological results of cooperability, it is worth noting the level of investment in R\&D. We emphasize that the portfolio of innovation projects (number of internal and cooperative projects), although relevant to the technological results the cooperability, exerts a negative impact on the results of managerial cooperability, indicating that the practices of portfolio management and the consequent alignment of internal and cooperative innovation projects may be biased in BMN. As the number of projects increases, it may raise the possibility of duplication of efforts and the maintenance of non-synergistic internal and external innovation processes (Figure 3), resulting in a potential negative impact on the results of managerial cooperability.

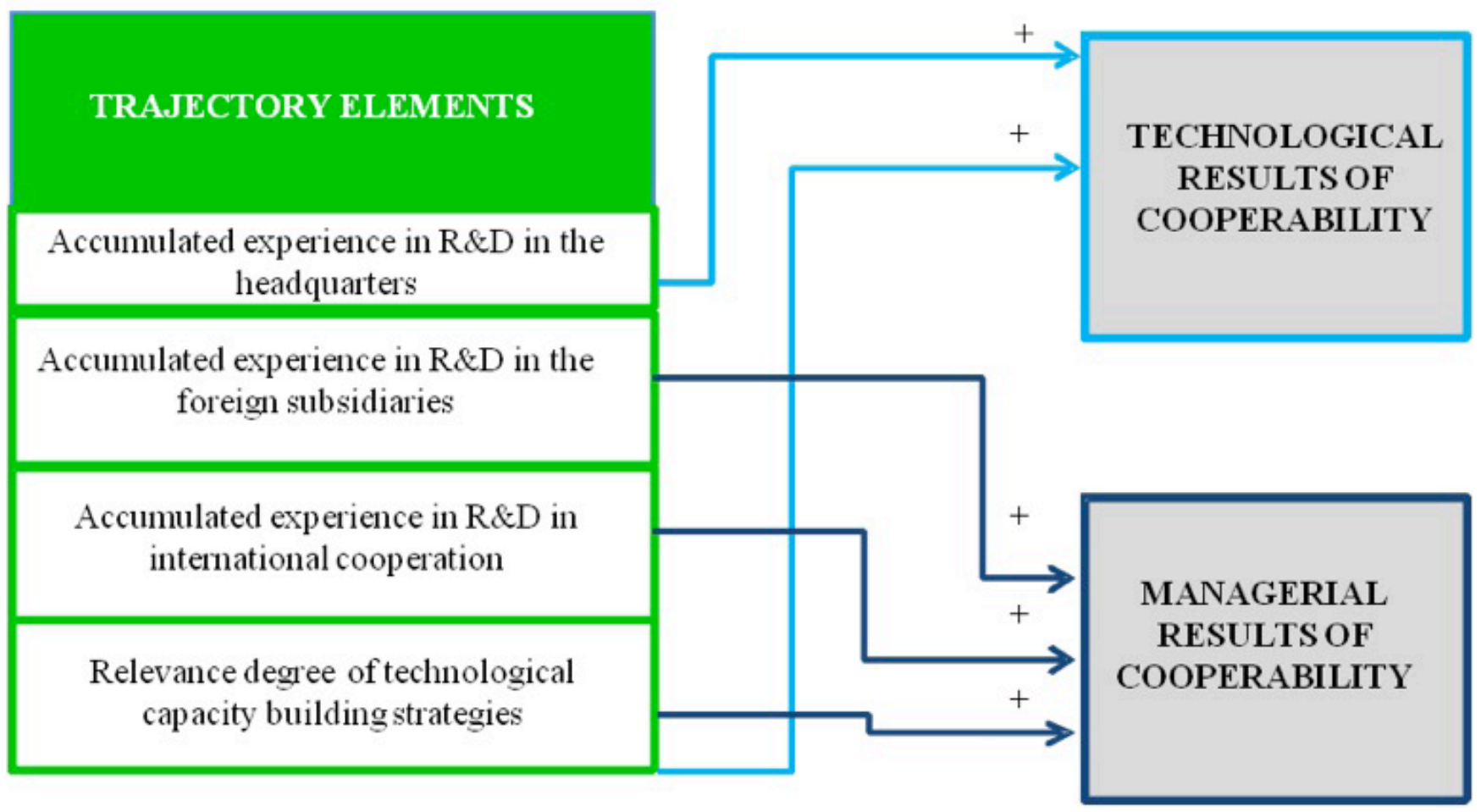

Figure 2. Summarization of hypothesis tests of the elements of the technological trajectory.

ISSN: 07 I8-2724. (http://www.jotmi.org)

Journal of Technology Management \& Innovation @ Universidad Alberto Hurtado, Facultad de Economía y Negocios. 
Considering the aggregate analysis of technological inputs, we conclude that the greater the level of investments in $R \& D$ and the number of internal and cooperative projects, the more effective will be the technological results. However, as the project portfolio is expanded, growing difficulties in aligning and managing by the $\mathrm{BMN}$, which may adversely affect the results of managerial cooperability (figure 3 ).
We emphasize as the limitations of this research that our findings are directly related to the 135 companies that participated in the survey, since its sampling process was intentional and not random. Thus, the conclusions should be considered with care, since this type of sampling does not permit generalizations about the findings of this investigation. We highlight for future studies the in-depth cooperability analysis of multinationals from developed economies and the realization of quantitative studies comparing the determinants of cooperability results of multinationals from BRICS (Brazil, Russia, India, China and Africa South).

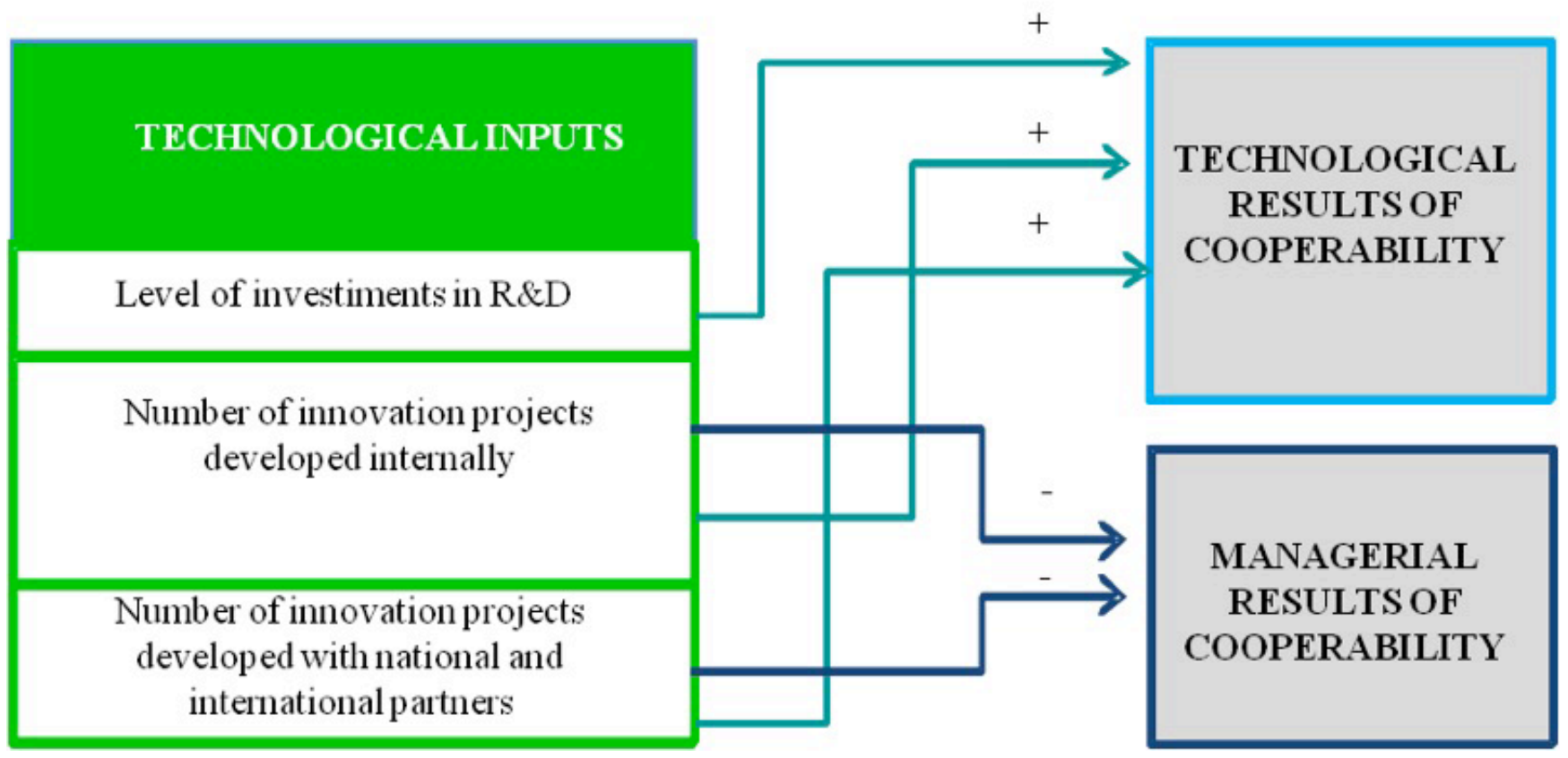

Figure 3. Summarization of hypothesis tests of technological inputs. 


\section{References}

ALMEIDA, A. (2007). Internacionalização de empresas brasileiras: perspectivas e riscos. Elsevier.

AMBOS, B., Schlegelmilch, B.B. (2007). Innovation and control in the multinational firm: a comparison of political and contingency approaches. Strategic Management Journal, 28, 473-486.

ANDRADE, C.A.A. (2010). Inovação e Externalização: Uma Análise de Capabilities na Indústria Farmacêutica. Tese (Doutorado em Engenharia de Produção) Departamento de Engenharia de Produção, Escola Politécnica, Universidade de São Paulo.

ASAKAWA, K., Nakamura, H., Sawada, N. (20I0). Firms' open innovation policies, laboratories' external collaborations, and laboratories' R\&D performance. R\&D Management, 40 (2), 109-1 23.

BARTLETT, C.A., Ghoshal, S. (1992). Gerenciando empresas no exterior: a solução transnacional. Tradução Maria Cláudia Santos R. Ratto, revisão técnica Carlos Osmar Bertero. Makron Books 2.

BERCOVITZ, J., Feldmann, M. (2006). Entpreprenerial Universities and Technology Transfer:A Conceptual Framework for Understanding Knowledge-Based Economic Development. Journal of Technology Transfer, 31, 175-I88.

BERGHE, L.V.D., Guild, P.D. (2008). The strategic value of new university technology and its impact on exclusivity of licensing transactions: An empirical study. Journal of Technology Transfer, 33, 91-I03.

BRUNEEL, J., Este, P.D., Salter, A., 20I0. Investigating the factors that diminish the barriers to university - industry collaboration. Research Policy, 39 (7), 858-868.

CARAYANNIS, E.G., Campbell, D.F.J. (2009). Mode 3 and Quadruple Helix : toward a 2 I st century fractual innovation ecosytem. International Journal of Technology Management, 46 (3/4), $20 \mathrm{I}-234$.

CHESBROUGH, H., Vanhaverbeke, W., West, J. (2008). Open innovation: researching a new paradigm. Oxford University Press.

CHIARONI, D., Chiesa, V., Frattini, F. (20II). Technovation The Open Innovation Journey: How firms dynamically implement the emerging innovation management paradigm. Technovation, 3I (I), 34-43.
CHIARONI, D., Chiesa, V.; Frattini, F. (20I0). Unravelling the process from Closed to Open Innovation: evidence from mature, asset-intensive industries. R\&D Management, 40 (3), 222-245.

CHIESA,V. (2000). Global R\&D Project Management and Organization: a taxonomy. Journal of Product Innovation Management, I 7 (5), 34|-359.

CRONBACH, J.L. (195I). Coefficient alpha and the internal structure of tests. Psychometrika, 16 (3), 297-334.

CYRINO, Á.B., Barcellos, E.P. (2006). Estratégias de internacionalização: evidências e reflexões sobre as empresas brasileiras. In: Tanure, B., Duarte, R.G. (Org.). Gestão internacional. Saraiva, 22I-246.

DOZ,Y., Santos, J.,Williamson, P. (200I). From Global to Metanational. Harvard Business School Press.

EISENHARDT, K.M., Martin, J.A. (2000). Dynamic capabilities: what are they? Strategic Management Journal, 2 I, I I05-I I 2 I.

ENGEROFF, R., Balestrin, A. (2008). Inovação fechada versus inovação aberta: um estudo de caso da indústria de cutelaria. In: Simpósio de Gestão da Inovação Tecnológica, XXV, ANPAD.

FERRO, A.F.P. (20I0). Gestão da inovação aberta: práticas e competências em P\&D Colaborativa. Tese (Doutorado em Política Científica e Tecnológica) Programa de Pós-Graduação em Política Científica e Tecnológica, Instituto de Geociências Universidade Estadual de Campinas.

GASSMANN, O., Enkel, E., Chesbrough, H., 20I0. The future of open innovation. R\&D Management, 40 (3), 2I 3-22I.

GASSMANN, O., Zedtwitz, M.V., 1999. New Concepts and Trends in International R\&D Organization. Research Policy, 28 (2), 23 I- 250.

GIL, A.C. (2002). Métodos e técnicas de pesquisa social. 4 ed. Atlas.

HAIR, J.F., Black, W.C., Babin, B.J., Anderson, R.E., Tatham, R. L. (2007). Análise multivariada de dados. Bookman.

HANEL, P., Pierre, M. (2006). Industry-University Collaboration by Canadian Manufacturing Firms. Journal of Technology Transfer, 3I, 485-499.

HEIMERIKS, K.H., Duysters, G., Vanhaverbeke, W. (2007). Learning mechanisms and differential performance in alliance portfolios. Strategic Organization, 5 (4), 373-408.

ISSN: 07 I8-2724. (http://www.jotmi.org)

Journal of Technology Management \& Innovation (c) Universidad Alberto Hurtado, Facultad de Economía y Negocios. 
HELFAT, C.E., Finkelstein, S., Mitchell, W., Peteraf, M.A., Singh, H., Teece, D.J., Winter, S.G. (2007). Dynamic capabilities. Blackwell Publishing.

HITT, M.A., Ireland, R.D., Hoskisson, R.E. (2008). Administração estratégica: competitividade e globalização. Thomson.

HOANG, H.A., Rothaermel, F.T. (20I0). Leveraging internal and external experience : exploration, exploitation , and R\&D project performance. Strategic Management Journal, 3 I (7), 734-758.

HOANG, H., Rothaermel, F.T. (2005). The effect of general and partner-specific alliance experience on joint R\&D project performance. Academy of Management Journal, 48 (2), 332-345.

KERLINGER, F.N. (1980). Metodologia de Pesquisa em Ciências Sociais. EPU.

KIM, C., Song, J. (2007). Creating new technology through alliances: an empiricalinvestigation of joint patents. Technovation, 27 (8), 46I-470.

LAI, J.H., Chang, S.C., Chen, S.S. (20I0). Is experience valuable in international strategic alliances? Journal of International Management, 16 (3), 247-26I.

LAURSENA, K., Salterb, A. (2004). Searching high and low: what types of firms use universities as a source of innovation?. Research Policy, 33 (8), |20|-|2|5.

LAVIE, D., Rosenkopf, L. (2006). Balancing exploration and exploitation in alliance formation. Academy of Management Journal, 49 (4), 797-818.

LEYDESDORFF, L., Meyer, M. (2006). Triple Helix indicators of knowledge-based innovation systems: Introduction to the special issue. Research Policy, 35 (I0), I44 I-I449.

LEYDESDORFF, L., Etzkowitz, H. (200I). The Transformation of University-industry-government Relations. Electronic Journal of Sociology, 5 (4), I- 17.

LIMA, M.C. (2008). Monografia: a engenharia da produção acadêmica. 2. ed. Saraiva.

O'CONNOR, G.C. (2008). Open, Radical Innovation: Toward an Integrated Model in large established firms. In: Chesbrough, H. Open Innovation: researching a new paradigm. Oxford.

PAGANO, M., Gauvreau, K. (2004). Princípios de bioestatística. $2^{a}$ ed.Thompson.
PETRUZZELLI, M. (20II). The impact of technological relatedness, prior ties, and geographical distance on university - industry collaborations :A joint-patent analysis. Technovation, 3I (7), 309-3I9.

PORTO, G., Galina, S., Costa, P.R., Moura, P., Mata, R. (20I0). Gestão de P\&D de empresas multinacionais brasileiras. In: Fleury, A. (Org.). Gestão Empresarial para a Internacionalização das Empresa Brasileiras. Atlas.

SAMPSON, R.C. (2005). Experience effects and collaborative returns in R\&D alliances. Strategic Management Journal, 26 (II), I009-I03I.

SANTOS, J. (2006). O desafio Metanacional. In: Tanure, B., Duarte, R. G. (Org.). Gestão Internacional. Saraiva.

SIMARD, C., West, J. (2008). Knowledge Networks and the Geographic Locus of Innovation. In: Chesbrough, H. Open Innovation: researching a new paradigm. Oxford.

TEECE, D.J., Pisano, G., Shuen, A. (1997). Dynamic Capabilities and Strategic Management. Strategic Management Journal, 18 (7), 509-533.

TEECE, D.J. (2007). Explicating dynamic capabilities: the nature and microfoundations of (sustainable) enterprise performance. Strategic Management Journal, 28 (13), I3 I9-1350.

VAN DER MEER, H. (2007). Open Innovation - The Dutch Treat: Challenges in Thinking in Business Models. Creativity and Innovation Management, 16 (2), 192-202.

VEUGELERS, R., Cassiman, B. (2005). R\&D cooperation between firms and universities. Some empirical evidence from Belgian manufacturing. International Journal of Industrial Organization, 23 (5), 355-379.

WASSMER, U. (2010). Alliance Portfolios: A Review and Research Agenda. Journal of Management, 36 (I), |4I-I7I.

WEST, J., Gallagher, S. (2008). Patterns of Open Innovation in Open Source Software. Open Innovation: researching a new paradigm, 235 (I I).

WINTER, S.G. (2003). Understanding Dynamic Capabilities. Strategic Management Journal, 24 (I0), 99I-995. 